\title{
Influence of drug treatment with antidepressants and antipsychotics on plasma urea levels
}

\author{
This article was published in the following Dove Press journal: \\ Neuropsychiatric Disease and Treatment \\ 8 June 2012 \\ Number of times this article has been viewed
}

\section{Roberto Lozano Ortiz \\ Pharmacy Department, Hospital Real Nuestra Señora de Gracia, Zaragoza, Spain}

Correspondence: Roberto Lozano Ortiz Pharmacy Department, Hospital Real Nuestra Señora de Gracia, Zaragoza, Ramon y Cajal 6050004 Zaragoza, Spain Tel +34976444300

$\mathrm{Fax}+34876764555$

Email rlozano@salud.aragon.es
Having read with great interest the article by Goto et $\mathrm{al}^{1}$ and in order to clarify further some of the results presented in this article, especially with regard to the action of atypical antipsychotic drugs on glutamate and the glutamine to creatine ratio, it would seem appropriate to reiterate the comments made by Lozano et al in a presentation at the 55th National Congress of the Spanish Association of Hospital Pharmacists in 2010, where we proposed the likely influence of antipsychotic treatment on nitric oxide, glutamine, and glutamate levels in the brain, as a result of the reaction of nitric oxide with glutamine to yield glutamate and nitrogen gas. A summary of this research is provided as follows.

Nitric oxide is believed to have a role in the pathophysiology of schizophrenia, depression, and anxiety disorders. In this longitudinal cohort study, we measured plasma urea levels to determine the influence of antidepressant and antipsychotic treatment on nitric oxide synthase activity and tissue nitric oxide concentrations in the brain. We recruited two groups, ie, 25 patients treated with the antipsychotic risperidone for at least 6 weeks (AP group) and 25 patients treated with the antidepressant escitalopram for at least 6 weeks (AD group). Student's $t$-test was used for the statistical analysis. The mean plasma urea level in the AD group was $37.7 \pm 10.5 \mathrm{mg} / \mathrm{dL}$ and in the AP group was $2.6 \pm 9.2 \mathrm{mg} / \mathrm{dL}$. The difference between the average value for plasma urea in group AP compared to that obtained for group AD was $11.1 \mathrm{mg} / \mathrm{dL}$ $(P<0.001)$.

Preclinical studies have demonstrated that inhibition of nitric oxide synthase produces anxiolytic-like and antidepressant-like behavioral effects, and that nitric oxide may modulate levels of various neurotransmitters in the central nervous system, eg, serotonin, dopamine, gamma aminobutyric acid, and glutamate. Our results suggest that nitric oxide produced by the action of nitric oxide synthase on L-arginine may react with nitrogen in the carbamoyl group on glutamine and, via enzymes with nitric oxide reductase activity, generate nitrogen gas and glutamic acid, thus changing the amount of urea formed by the action of arginase on arginine and, therefore, its concentration in blood. Thus, treatment with antidepressants or antipsychotics could alter the metabolic pathway of arginine to yield urea or nitric oxide/nitrogen gas, increasing (if AP) or decreasing (if AD) urea or nitric oxide/nitrogen gas and, secondarily, excitatory glutamic acid and/or inhibitory gamma aminobutyric acid levels via different pathways in the central nervous system. 


\section{Disclosure}

The author reports no conflicts of interest in this work.

\section{References}

1. Goto N, Yoshimura R, Kakeda S, et al. Six-month treatment with atypical antipsychotic drugs decreased frontal-lobe levels of glutamate plus glutamine in early-stage first-episode schizophrenia. Neuropsychiatr Dis Treat. 2012;8:119-122.
2. Lozano, et al. Study of the influence of drug treatment with antidepressants and antipsychotics on plasma urea. Presentation at the 55th National Congress of the Spanish Association of Hospital Pharmacists, Madrid, Spain, October 19-22, 2010.

3. Lozano R. The action of nitrogen on glutamate concentration: Adding to the discussion. Undersea Hyperb Med. 2012, Vol. 39, No.1:618 (in press).

\section{Publish your work in this journal}

Neuropsychiatric Disease and Treatment is an international, peerreviewed journal of clinical therapeutics and pharmacology focusing on concise rapid reporting of clinical or pre-clinical studies on a range of neuropsychiatric and neurological disorders. This journal is indexed on PubMed Central, the 'PsycINFO' database and CAS.

The manuscript management system is completely online and includes a very quick and fair peer-review system, which is all easy to use. Visit http://www.dovepress.com/testimonials.php to read real quotes from published authors.

Submit your manuscript here: http://www.dovepress.com/neuropsychiatric-disease-and-treatment-journal 